\title{
Contribution Factors on Early Initiation of Breastfeeding
}

\author{
Dwifitria Ariyani, Lina Handayani \\ Faculty of Public Health, Universitas Ahmad Dahlan, Yogyakarta, Indonesia
}

\begin{tabular}{l} 
Article Info \\
\hline Article history: \\
Received Jun 9, 2015 \\
Revised Aug 20, 2015 \\
Accepted Aug 28, 2 \\
\hline Keyword: \\
Attitude \\
EIB \\
Knowledge \\
Role of Midwives
\end{tabular}

Article Info

rticle history:

Received Jun 9, 2015

Revised Aug 20, 2015

Role of Midwives

\begin{abstract}
One of the causes of high Infant Mortality Rate is the low coverage of exclusive breastfeeding. One of the supporting factors to exclusive breastfeeding is implementation of Early Initiation of Breastfeeding (EIB). Mother's knowledge and understanding about the EIB, as well as the role of birth attendants, especially midwives can be strongly support it's the EIB. The purpose of this research was to determine the relationship between mother's knowledge, mother's attitudes and midwife role with the implementation of Early Initiation of Breastfeeding (EIB). The research was an observational analytic research employed cross sectional design. The subjects were maternity mothers who inpatient at Pulang Pisau Hospital in Central Kalimantan Province, Indonesia. The results showed that there were significant relationships between mother's knowledge, attitudes and midwife role with the Implementation of Early Initiation of Breastfeeding (EIB). Attitude was the most influenced variable to the EIB.
\end{abstract}

Copyright (c) 2015 Institute of Advanced Engineering and Science. All rights reserved.

\section{Corresponding Author:}

Lina Handayani, Faculty of Public Health , Universitas Ahmad Dahlan,

Jl. Prof. Dr Soepomo Janturan Yogyakarta 55164, Indonesia.

Email: linafkm@gmail.com

\section{INTRODUCTION}

Exclusive breastfeeding is very important to promote infant health. However, almost all districts in Indonesia do not reach the national target for exclusive breastfeeding. The main problem of the low exclusive breastfeeding is the lack of knowledge of pregnant women, families and communities about the importance of breastfeeding. One that supports the success of exclusive breastfeeding is to implement a program of Early Initiation of Breastfeeding (EIB). EIB is the process of looking for a baby to the mother's nipple itself or start feeding themselves after birth by placing among the abdomen or chest and let the skin contact between baby's skin to mother skin [1].

EIB role in achieving the objectives of the Millennium Development Goals (MDGs) which is helping to reduce poverty and hunger and also reducing child mortality with the target of reducing deaths by 2/3 from 1990 to 2015. The other benefits of EIB are: helping the baby gets the milk first, improving milk production, building a bond of love between mother and child [1].

There are several factors that cause EIB process is not carried out, namely maternal factors and infant factors. Factors such mothers from maternal physical factors weakened after childbirth and psychological factors of mother that affect the oxytocin hormone. Predisposition factors of exclusive breastfeeding failure due to the lack of knowledge and experience of mothers and the mother is not facilitated to EIB [2].

Knowledge and attitude are important factors in the formation of someone's actions. The better knowledge of the mother about the EIB will help mothers in breastfeeding as early as possible. The role of health workers as a birth attendant was very supportive accomplished to EIB. During the mother's pregnancy, midwives provide information about the IMD so when doing labor and mother facilitated to EIB, the mother 
will be motivated to breastfeed as early as possible to her infant [3]. The use of antenatal care (ANC) found to be correlated with timely initiation of breastfeeding [4]-[6].

\section{RESEARCH METHOD}

This was an observational analytic research employed cross sectional design. This design studied the correlation between risk factors and the effects of the approach, observation or the collection of data at a time [7]. Cross-sectional design was chosen to examine the independent variables are knowledge, mother's attitude and role of the midwife with dependent variable is the implementation of early breastfeeding initiation at the same time.

The instrument used in this study was a questionnaire containing questions about the name, age, education, knowledge, attitude and role of the midwife with the implementation of the EIB. Before being used in research, the questionnaire is tested for the validity and reliability first. The result showed that the reliability is good (the Cronbach alpha value was 0.602).

\section{RESULTS AND ANALYSIS}

The description of mother's knowledge about EIB presented in Table 1. Based on Table 1, it can be seen that more respondents were categorized as less knowledgeable about EIB (64.4\%).

Table 1. Mother's knowledge about EIB

\begin{tabular}{ccc}
\hline Knowledge & Number & Percentage (\%) \\
\hline Less & 29 & 64.4 \\
Good & 16 & 35.6 \\
Total & 45 & 100 \\
\hline
\end{tabular}

The description of mother's attitude toward EIB can be seen in Table 2. Table 2 shows that more respondents were categorized as having poor attitude toward EIB (53.3\%)

Table 2. Mother's attitude toward EIB

\begin{tabular}{ccc}
\hline Attitude & Number & Percentage (\%) \\
\hline Less & 24 & 53.3 \\
Good & 21 & 46.7 \\
Total & 45 & 100 \\
\hline
\end{tabular}

The description of midwife's role towards the implementation of the EIB is presented in Table 3. Based on Table 3, it can be seen that majority of the midwife support the implementation of the EIB (82.2\%).

Table 3. Midwife's role towards the implementation of the EIB

\begin{tabular}{ccc}
\hline Role of Midwives & Number & Percentage (\%) \\
\hline Does not support & 8 & 17.8 \\
Support & 37 & 82.2 \\
Total & 45 & 100 \\
\hline
\end{tabular}

Table 4 provides the description about the implementation of EIB. Table 4 informs that more mothers practice EIB (57.8\%).

Table 4. Implementation of EIB

\begin{tabular}{ccc}
\hline EIB & Number & Percentage (\%) \\
\hline Not implementing & 19 & 42.2 \\
Implementing & 26 & 57.8 \\
Total & 45 & 100 \\
\hline
\end{tabular}


The relationships between variables tested by Spearman correlation test and the result are shwon in Table 5. Table 5 shows that all independent variables (knowledge, attitude, role of midwives) correlate to dependent variable (EIB).

Table 5. Spearman correlation test's result

\begin{tabular}{lcc}
\hline \multicolumn{1}{c}{ Independent Variables } & Value & Dependent variable \\
\hline Attitude & $\mathrm{r}=0.657$ & \\
Knowledge & $p=0,000$ & \\
& $\mathrm{r}=0.478$ & \\
Role of midwives & $p=0,001$ & \\
& $\mathrm{r}=0.403$ & \\
& $p=0.006$ & \\
\hline
\end{tabular}

Linear regression test employed to determine the most variable influenced EIB. The result of this test is shwon in Table 6. Based on Table 6 it can be seen that the p- value of all variables are 0.000. It means that all variables has a significant relationship because $p$ value $<0.05$.

Table 6. Results of linear regression's test

\begin{tabular}{ccc}
\hline Variables & The correlation coefficient & p-value \\
\hline Attitude & 0.569 & 0,000 \\
Knowledge & 0.403 & 0,000 \\
Role of midwives & 0.362 & 0,000 \\
\hline
\end{tabular}

There are significant relationships between mother's knowledge, mother's attitudes and the midwife's role in the implementation of the EIB. The strength of the relationship can be seen from the value of $\mathrm{r}$ (correlation coefficient). The strength of the relationship from the largest to smallest are the attitude $(\mathrm{r}=$ 0.569), knowledge $(r=0.403)$ and the role of midwives $(r=0.362)$. It means that attitude is the most influenced variable to $\mathrm{EIB}$, with $\mathrm{r}$ value $=0.569$ that indicates a strong correlation.

\subsection{Discussions}

\subsubsection{The relationship between mother's knowledge and EIB}

The results of Spearman correlation test obtained p-value of 0.001 . It means that there is a relationship between knowledge and the EIB. The strength of the relationship indicated by the value of $\mathrm{r}$ value $=0,478$. It means that the strength of the correlation is moderate or sufficient.

The result of multivariate analysis using linear regression test obtained p-value of 0.000 . This shows that there is a significant relationship between knowledge and implementation of the EIB. The strength of the relationship that is equal to 0.403 and included in the category of moderate or sufficient correlation. This results support previous research conducted by Solihah in 2010. She found that mother's knowledge about the benefits of breastfeeding influence the decision of early breastfeeding to newborns [8].

The result of current research indicates that more knowledgeable mother, more practicing the EIB and vice versa. The result is similar with another previous research resulted that there is a significant association between mother's knowledge with implementation of EIB [9]. Moreover, Vasra (2013) in her research also concluded that there is a significant relationship between mother's knowledge and the EIB [10].

\subsubsection{The relationship between mother's attitude with EIB}

The result of current research showed that more mothers have poor attitude towards the EIB (53.3\%). It is in line with previous research resulted that the majority of mothers have less supportive attitude to the implementation of EIB [11]. This happens for several reasons: mother feels uncomfortable because the baby is not cleaned; the mother feels exhausted by childbirth and still feels bothered after childbirth.

Spearman correlation test obtained p-value $=0.000$, it means that there is a relationship between attitudes to the implementation of the EIB. The strength of the relationship indicated by $r$-value $=0.657$ which means strong correlation between variables.

Linear regression test obtained $p$-value $=0.000$. It shows that there is a significant relationship between attitude and EIB. The strength of the relationship obtained by r-value $=0.569$; it shows a strong 
correlation between variables. Multivariate test showed that attitude is the most influential variable on the implementation of the EIB compared to other variables.

Results of this research are not similar with previous research conducted by Issyaputri which stated that there is no relationship between attitude and mothers who did EIB [12]. These differences may because in Issyaputri's research not all mothers have a good attitude towards EIB will do EIB. It is influenced by the lack of support from health workers and motivation itself. Other research also stated that there is no relationship between attitude and the implementation of EIB [13]. However, the current result is in line with the theory by Notoatmodjo. Attitude is predisposition factor (determinant factor) associated with the person's behavior [7].

Attitude is a predisposition or a learned tendency by individuals to respond positively or negatively with moderate intensity or adequate to the object, situation, concept, or others. Attitude will arise because of the considerations derived from information or knowledge gained. This is consistent with the theory states that people will consider the gains and losses of behavior that accordance with the analysis ofthem [11].

\subsubsection{The relationship between the Role of Midwives with EIB}

The current result found that most midwives support the implementation of the EIB (82.2\%). This is support previous research conclude that babies born in hospitals supported by health workers would be more likely to EIB compared with babies born without supported by health workers [14].

The Spearman correlation test obtained $\mathrm{p}$ - value $=0.006$, which means that there is a relationship between the midwife's role with the implementation of the EIB. The strength of the relationship indicated by $\mathrm{r}$-value $=0.403$; it is included in the category of moderate or sufficient correlation .

Multivariate analysis employing linear regression test obtained $\mathrm{p}$-value $=0.000$. This shows a significant relationship between the role of midwife to the implementation of the EIB. The strength of the relationship obtained by $r$-value $=0.362$ which indicates a very weak correlation .

The results are consistent with previous research that states that there is a relationship between the role of health workers with by EIB [15]. Other research also suggested that the role of health workers towards the EIB has significant relationship [16]. The current finding is also in line with previous study in Nepal [17]. Support provided health personnel will generate confidence in the mother's decision to breastfeed her infant [18].

Similar with current finding, three studies in Asia [19]-[21] have also reported that the skilled birth attendants support postpartum mothers for timely initiation of breastfeeding. Health workers are expected to take the time to motivate and to help mother's maternity so that it can carry out the EIB and exclusive breastfeeding. Another previous research found that good clinical support towards EIB can encourage increasing EIB by mother [22].

\subsubsection{Attitude was the most influential variable on the implementation of EIB}

Linier regression test resulted that the three variables has a significant relationship with the p-value 0.000. The strength of the relationship from the largest to smallest is the attitude of the mother $(r=0.569)$, mother's knowledge $(r=0.403)$ and the role of midwife $(r=0.362)$. It can be seen that the most influenced variable on the implementation of EIB is the attitude which shows a strong correlation.

Table 2 shows that only $46.7 \%$ mothers have positive attitude toward EIB. Mothers who are less supportive attitude to EIB occurs because the physical condition of the mother who was still tired from the birth process. Most of the mothers refused on the grounds that the conditions are still weak and also sometimes not all officers implementing the EIB to postpartum mothers. Officers who do not implement the EIB due to the lack of coordination between the officers so that the division of tasks becomes uneven. The childbirth process more assisted by a midwife while the obstetrician rarely was in the hospital. The presence of an obstetrician can also help motivate the mother in order to have a positive attitude so as to support the implementation of the EIB. The absence of hospital policies that oblige health workers to implement the EIB, so if there are health workers who do not implement the EIB will not be a problem.

Mothers who are less supportive attitude toEIB may also be influenced by emotional factors. Stable emotional state determines the positive attitude of mothers. Emotional stability can be achieved when a husband or family provides adequate support and motivation. Support gives an impression that she is loved and cared for, has pride and valued so that by it will affect the emotional. Mother will be more calm, comfortable and confident to do EIB [23].

\section{CONCLUSION AND SUGGESTIONS}

Based on the results and discussion, it can be concluded that mother's knowledge, attitude and the role of midwives correlate to EIB. Attitude is the most influenced variable to EIB. 
Midwives need to provide information related to EIB. They can educate mother during antenatal care ANC. Hopefully, mother will be better understanding about the importance of EIB. It also distributed a handbook to pregnant women that contain the material about EIB and also implementation procedures of EIB.

\section{REFERENCES}

[1] Kementrian Kesehatan RI, “Basic Health Research”, 2010. http://www. depkes. go. id/resources/download/pusdatin/infodatin/infodatin-asi. pdf, akses tanggal 15 november 2014.

[2] Fikawati, S., Syafiq, A., " Exclusive breastfeeding, the causes of succesfullness and failure”, Jurnal Kesmas Nasional, vol/issue: 4(3), pp. 120-131, 2010.

[3] Dianartiana, A., " The relationship between early initiation of breastfeeding and the successfull of breastfeeding for mothers' of 7-12 months baby in Semarang City, Jurnal Dinamika Kebidanan, vol/issue: 1(2), pp. 1-13, 2011.

[4] Archana P. Banerjee A., Kaletwad A., "Factors associated with prelacteal feeding and timely initiation of breastfeeding in hospital delivered infants in India”, J. Hum. Lact., vol/issue: 29(4), pp. 572-578, 2013.

[5] Tang L., Binns C. W., Lee A. H., Pan X., Chen S., Yu C., "Low prevalence of breastfeeding initiation within the first hour of life in a rural area of Sichuan Province”, China Birth, vol/issue: 40(2), pp. 134-142, 2013.

[6] Vieira T., Vieira G., Giugliani E., Mendes C., Martinus C., Silva L., "Determinants of breastfeeding initiation within the first hour of life in a Brazilian population: cross-sectional study”, BMC Public Health, vol. 10, pp. 760, 2010.

[7] Notoatmodjo, S., “Conceptual of health behaviour in health promotion: Theory dan application”, Revised Edition V, Rineka Cipta, Jakarta, 2010.

[8] Ii Solihah, “Factors related to exclusive breastfeeding in first hour after born in Garut, West Java” Jurnal Kesehatan Media Litbang Kesehatan, vol/issue: 20(2), 2010.

[9] Wahyuningsih, “The relationship between mothers' knowledge with EIB at private midwive practice Benis Jayanto Ngentak Kujon Ceper Klaten”, Jurnal Akbid Bhakti Putra Bangsa Purworejo, vol/issue: 3(1), pp. 1-5, 2012.

[10] Vasra, "The relationships between knowledge and education with EIB at BPS Ellna Pasar Kuto Palembang", Skripsi, Politeknik Kesehatan Palembang, 2013.

[11] Budi Rahardjo, Bambang, "Mother's profile and midwive's role in EIB and exclusive breastfeeding”, Jurnal Kesehatan Masyarakat, Program Doktor Studi Pembangunan, Universitas Kristen Satya Wacana Salatiga, vol/issue: 10(1), pp. 53-63, 2014.

[12] Issyaputri, "Factor related to EIB at RSIA Siti Fatimah Makassar 2011”, Jurnal MKMI, vol/issue: 6(2), pp. 17-24, 2011.

[13] Fransisca, Benny, Julia, “ The relationships between knowledge, attitude with EIB at VK Irina Room RSUP Prof. R. D. Kandoumanado, Jurnal e-Ners, vol/issue: 1(1), pp. 1-5, 2013.

[14] Roesli, Utami, "Guidance of EIB plus exclusive breastfeeding”, first edition, Pustaka Bunda, Jakarta, 2008.

[15] Fauziah, "Factors related to first time breastfeeding on newborn at RSUD Kota Jakarta”, Skripsi, Fakultas Kedokteran dan Ilmu Kesehatan, Universitas Islam Negeri Syarif Hidayatullah, 2009.

[16] Indramukti, "Factors related to EIB on normal postpartum mother", Unnes Journal of Public Health, vol/issue: 3(12), pp. 1-5, 2013.

[17] Andhikari, et. al., "Factors associated with early initiation of breastfeeding among Nepalese mothers: further analysis of Nepal Demographic and Health Survey 2011”, International Breastfeeding Journal, vol. 9, pp. 21, 2014.

[18] Departemen Kesehatan Republik Indonesia, "Policy of Health Department about enhancement of breastfeeding on women worker”, Pusat Kesehatan Kerja Depkes RI, Jakarta, 2005.

[19] Ma B., Tighe S., "Facilitating effective initiation of breastfeeding-a review of the recent evidence base", $\mathrm{Br} J$ Mildwifery, vol/issue: 21(5), pp. 312-315, 2013.

[20] Duong D. V., Binns C. W., Lee A. H., "Breastfeeding initiation and exclusive breastfeeding in rural Vietnam", Public Health Nutr, vol/issue: 7(6), pp. 795-800, 2004.

[21] Senarath U., Siriwardena I., Godakandage S. S. P., Jayawickrama H., Fernando D. N., Dibley M. J., "Determinants of breastfeeding practices: An analysis of the Sri Lanka Demographic and Health Survey 2006-2007”, Matern Child Nutr, vol/issue: 8(3), pp. 315-329, 2012.

[22] Kornides, Melanie, Panagiota, Kitsantas, "Evaluation of Breastfeeding Promotion, Support and Knowledge of Benefit or Breastfeeding outcomes”, Journal of Child Health Care, vol. 17, pp. 264-273, 2013.

[23] Sutriyani, Sirajuddin, Tahir, “ Determinat of EIB”, Jurnal Kesehatan Masyarakat Nasional, vol/issue: 8(3), pp. 1-5, 2012. 